\title{
Clinical Reasoning: A Teenager With Shortness of Breath and Difficulty Walking
}

Suzanne C. Liu, MD, Jason T. Poon, MD, and Meghan S. Candee, MD

Neurology ${ }^{\circledR}$ 2021;96:e2346-e2350. doi:10.1212/WNL.0000000000011544
Correspondence

Dr. Liu

suzanne.liu@hsc.utah.edu

\section{Section 1}

A 13-year-old boy presented to an urgent care clinic with 4 days of fatigue, vomiting, shortness of breath, and difficulty ambulating. Aside from a recent viral upper respiratory infection, he was healthy. He was sent to the emergency department, where weakness was noted in his lower extremities and right arm. Within hours, he declined, was emergently intubated for respiratory distress, and was transferred to a children's hospital.

On our examination, the patient was awake, alert, oriented, and able to answer questions with finger movements. Pupils were equal, normal size, and briskly reactive to light. He displayed mild downgaze nystagmus, incomplete eye closure, tongue weakness, and asymmetric ptosis. Gag reflex was absent. He had normal muscle bulk but diffusely decreased tone. He had proximal weakness $(2 / 5)$ in all extremities and asymmetric distal weakness ( 3 to $4-/ 5)$. Reflexes were patchy throughout. Sensation was normal. Coordination and gait testing were limited due to weakness.

\section{Question for Consideration:}

1. What is your differential?

\section{GO TO SECTION 2}




\section{Section 2}

The differential for acute onset weakness with respiratory compromise includes Guillain-Barré syndrome (GBS), juvenile myasthenia gravis (JMG), Lambert-Eaton myasthenic syndrome (LEMS), hyperthyroidism, and botulism.

Myasthenia gravis (MG) is an autoimmune disease with antibodies targeting the postsynaptic neuromuscular junction (NMJ) resulting in fluctuating bulbar and limb muscle weakness that is fatigable, painless, and improves with rest. Patients with JMG initially present with ptosis and other ocular symptoms, progressing to generalized weakness and infrequently, respiratory distress necessitating intubation. ${ }^{1}$

LEMS is an autoimmune or paraneoplastic disease with antibodies targeting P/Q-type voltage-gated calcium channels in the presynaptic NMJ resulting in ptosis, dysautonomia, hyporeflexia, and proximal and progressive muscle weakness. Although LEMS was considered, it would be unlikely given the acute presentation and our patient's age. In a recent literature review, only 12 pediatric patients with LEMS were reported. ${ }^{2}$

Hyperthyroidism was considered and our patient had limited ophthalmoplegia, but no other signs of Graves ophthalmopathy. Thyroid storm could cause acute respiratory failure, altered mentation, and generalized weakness, but is uncommonly seen in pediatric patients. ${ }^{3}$

GBS often presents 2-4 weeks after a gastrointestinal or respiratory illness, typically with ascending weakness, pain, and difficulty walking. ${ }^{4}$ About $50 \%$ of pediatric patients develop autonomic dysregulation symptoms, which include labile blood pressures, ileus, and bladder dysfunction. ${ }^{5}$ Pediatric patients presenting with Miller Fisher syndrome (MFS), a GBS variant known for the triad of ataxia, ophthalmoplegia, and areflexia, have been reported. ${ }^{4}$ MFS is associated with bulbar (progressing to widespread) weakness. Another variant is the acute motor axonal neuropathy (AMAN) form, associated with severe motor deficits but no associated sensory abnormalities. ${ }^{5}$ Pediatric GBS can, albeit rarely, present with acute-onset respiratory failure. ${ }^{4}$

Foodborne botulism is a frequent concern with exposure to home-canned foods. Botulinum toxin blocks neurotransmitter release at the NMJ resulting in descending, flaccid paralysis. ${ }^{6}$ Typically, the incubation period is about $12-48$ hours after ingestion. ${ }^{6}$ Our patient, his parent, and a friend consumed home-canned green beans about 4 days before presentation. However, no one else was symptomatic at the time.

\section{Question for Consideration:}

1. What diagnostic tests would you order?

\section{GO TO SECTION 3}




\section{Section 3}

We assessed for thyroid derangements but no abnormalities were seen in thyroid-stimulating hormone, blood counts, metabolic panels, or systemic inflammatory markers. Toxicology screens were normal.

As evidence against MG, we demonstrated lack of antibodies against acetylcholine receptor and muscle-specific receptor tyrosine kinase. Our patient had a mildly positive anti-Titin antibody, which is more frequently seen in patients with $M G$ with a thymoma, but CT was negative for thymoma. A trial of pyridostigmine was not supportive of JMG. Negative voltage-gated calcium channel antibodies effectively ruled out LEMS.

In patients with GBS, classic findings include elevated CSF protein and albuminocytologic dissociation with spinal nerve root enhancement on MRI. However, CSF testing was normal on day 5 and day 10 of illness and spinal and brain MRIs on day 10 of illness were normal. Anti-GQ1b antibody was tested when suspecting the MFS variant of GBS and was negative.

Nerve conduction studies performed on day of admission showed slightly low-amplitude ulnar motor response and absent blink responses. Abnormal repetitive nerve stimulation (RNS) findings are seen in patients with LEMS and MG; our patient's $3 \mathrm{~Hz}$ ulnar RNS showed no decrement and $50 \mathrm{~Hz}$ RNS showed no facilitation.

Our patient's constipation was treated with glycerin suppositories; however, glycerin invalidates stool botulinum toxin testing and a glycerin-free sample could not be obtained. No serum botulinum toxin testing was sent.

\section{Question for Consideration:}

1. What is the most likely diagnosis? 


\section{Section 4}

With exposure to home-canned food, there was concern for foodborne botulism. However, our patient did not show any pupillary abnormalities, nor was there clear, directional progression of his weakness.

We suspected that our patient had the MFS variant of GBS despite normal protein in the CSF and normal imaging. While both of these signs are helpful when present, their absence does not rule out GBS. ${ }^{5}$ Furthermore, the abnormal blink reflex on electrodiagnostic testing and clinical history seemed to be consistent. He was treated early on with IV immunoglobulin (IVIg) and had mild improvement in his hand strength within a week. Over the next month, he continued to have weakness and a tracheostomy was placed. Sweating and intermittent hypertension occurred, both expected with dysautonomia in GBS. IVIg was repeated 2 weeks after his initial dose with mild improvement. Repeat electrodiagnostic testing 40 days after initial symptoms showed axonal motor neuropathy with mild to moderate denervation. Our working diagnosis changed to the AMAN variant of GBS.

On hospital day 24, a friend of the patient was seen in our clinic. He was a 14-year-old boy who noticed fatigue, proximal weakness, altered ambulation, and difficulty swallowing around the same time as our patient but now had stabilized symptoms. This patient's only abnormal findings were decreased muscle bulk in bilateral upper extremities, 4/5 strength in his proximal muscles, and difficulty rising from a supine position. He had eaten the same green beans as our first patient, but only took "a small bite." Myositis panel, creatinine kinase level, and screening for neuromuscular autoimmune disorders were all normal. Electrodiagnostic testing on day 32 of his symptoms showed normal 3-Hz RNS but low-amplitude motor units with early recruitment, concerning for an acute myopathic process.

Prior to further workup on the second patient, 47 days after our first patient showed symptoms, we were alerted to our first patient's mother being hospitalized with acute respiratory failure. The green beans she had canned tested positive for botulinum toxin.

\section{Discussion}

Botulism is a rare and potentially fatal illness caused by exposure to the botulinum toxin, formed by spores from the ubiquitous Clostridium botulinum. Subtypes include wound, infant, intestinal toxemia, and foodborne. ${ }^{6}$ For the botulinum spores to germinate and produce the heat-labile botulinum toxin, the environment must be anaerobic and nonacidic, with low salt and sugar content. ${ }^{7}$ These conditions can be seen in home-canned vegetables and fermented fish, the 2 most common causes of foodborne botulism in the United States. ${ }^{7}$
In the systemic circulation, the neurotoxin binds irreversibly to the presynaptic motor-neuron terminals and blocks acetylcholine transmission across the NMJ. ${ }^{8}$ This causes bulbar weakness, respiratory compromise, and descending, symmetric, flaccid paralysis. Other commonly cited signs include ophthalmoplegia, other cranial nerve palsies, pupillary abnormalities, and severe constipation. ${ }^{6}$ Dysautonomia can be seen in the form of dry mouth and heart rate and blood pressure fluctuations. ${ }^{6}$ The affected nerve terminals regenerate slowly, and full recovery is seen in $95 \%$ of patients. ${ }^{7}$ The sensorium is preserved as the toxin is too large to cross the blood-brain barrier. ${ }^{8}$

The diagnosis is confirmed by testing stool, serum, or a suspected food source. Stool, enema, and gastric samples are preferred for toxin assays and cultures. ${ }^{9}$ However, if the samples are contaminated, such as with glycerin in treatments for constipation, test results are inconclusive. Although serum toxin assays are helpful, they typically only remain positive for up to 16 days after admission. ${ }^{6}$

Management consists of early diagnosis, supportive care, and timely antitoxin administration. In our patient, antitoxin was unlikely to be beneficial 54 days after symptom onset and circulating toxin was unlikely to remain. Nonspecific binding of IVIg to circulating toxin may have slowed disease progression, but his mild improvements were likely related to the natural course of the disease.

Our case highlights the difficulty of quick and accurate diagnosis of botulism as presenting signs overlap with other neuromuscular diseases when an obvious source has not yet been identified. Early symptoms of pediatric GBS can overlap that of botulism, with respiratory failure, limb and bulbar weakness, and decreased reflexes seen in either disorder. Distinguishing features of GBS, such as elevated CSF protein and electrodiagnostic abnormalities, may be delayed for up to 2 weeks. ${ }^{5}$ In botulism, electrodiagnostic features of reduced compound muscle action potential amplitudes and incremental response to rapid RNS are expected but may be absent. $^{10}$

Although our patient did not have definitive testing done for the botulinum toxin, nor were his electrodiagnostic studies conclusive, his clinical course and the exposure history eventually proved to be consistent with botulinum neurotoxicity. All mentioned patients made full recoveries without further neurologic sequelae.

\section{Study Funding}

No targeted funding reported.

\section{Disclosure}

The authors report no disclosures relevant to the manuscript. Go to Neurology.org/ $\mathrm{N}$ for full disclosures. 


\section{Appendix Authors}

\begin{tabular}{lll}
\hline Name & Location & Contribution \\
\hline $\begin{array}{l}\text { Suzanne } \\
\text { C. Liu, MD }\end{array}$ & $\begin{array}{l}\text { University of Utah/Primary } \\
\text { Children's Hospital, Salt } \\
\text { Lake City }\end{array}$ & $\begin{array}{l}\text { Cared for patients, drafted and } \\
\text { revised the manuscript for } \\
\text { content, concept, and design }\end{array}$ \\
\hline $\begin{array}{l}\text { Jason T. } \\
\text { Poon, MD }\end{array}$ & $\begin{array}{l}\text { University of Utah, Salt } \\
\text { Lake City }\end{array}$ & $\begin{array}{l}\text { Cared for patients, drafted and } \\
\text { revised the manuscript for } \\
\text { content, concept, and design }\end{array}$ \\
$\begin{array}{l}\text { Meghan S. } \\
\text { Candee, } \\
\text { MD }\end{array}$ & $\begin{array}{l}\text { University of Utah/Primary } \\
\text { Children's Hospital, Salt }\end{array}$ & $\begin{array}{l}\text { Cared for patients, revised } \\
\text { the manuscript }\end{array}$ \\
\hline
\end{tabular}

\section{References}

1. Finnis MF, Jayawant S. Juvenile myasthenia gravis: a paediatric perspective. Autoimmune Dis 2011;2011:404101.
2. Hajjar M, Markowitz J, Darras BT, et al. Lambert-Eaton syndrome, an unrecognized treatable pediatric neuromuscular disorder: three patients and literature review. Pediatr Neurol 2014;50:11-17.

3. LaFranchi S. Clinical manifestations and diagnosis of Graves disease in children and adolescents. In: UpToDate [online]. Available at: uptodate.com. Accessed July 29, 2020.

4. Ryan MM. Pediatric Guillain-Barré syndrome. Curr Opin Pediatr 2013;25: 689-693.

5. Korinthenberg R, Schessl J, Kirschner J. Clinical presentation and course of childhood Guillain-Barré syndrome: a prospective multicentre study. Neuropediatrics 2007;38: $10-17$.

6. Carrillo-Marquez MA. Botulism. Pediatr Rev 2016;37:183-192.

7. Sobel J. Botulism. Clin Infect Dis 2005;41:1167-1173.

8. Sugiyama H. Clostridium botulinum neurotoxin. Microbiol Rev 1980;44: $419-448$.

9. Centers for Disease Control and Prevention. Botulism in the United States, 1899-1996: Handbook for Epidemiologists, Clinicians, and Laboratory Workers. Atlanta: Centers for Disease Control and Prevention; 1998.

10. Chung L, Burbank E, Afra P, et al. Clinical and electrodiagnostic features of an outbreak of foodborne botulism due to Home-Brew alcohol among prisoners. Neurology 2012;78:P04.093. Abstract. 


\section{Neurology}

\section{Clinical Reasoning: A Teenager With Shortness of Breath and Difficulty Walking}

Suzanne C. Liu, Jason T. Poon and Meghan S. Candee

Neurology 2021;96;e2346-e2350 Published Online before print January 27, 2021

DOI 10.1212/WNL.0000000000011544

This information is current as of January 27, 2021

$\begin{array}{ll}\begin{array}{l}\text { Updated Information \& } \\ \text { Services }\end{array} & \begin{array}{l}\text { including high resolution figures, can be found at: } \\ \text { http://n.neurology.org/content/96/18/e2346.full }\end{array} \\ \text { References } & \text { This article cites } 8 \text { articles, } 2 \text { of which you can access for free at: } \\ \text { http://n.neurology.org/content/96/18/e2346.full\#ref-list-1 } & \text { This article, along with others on similar topics, appears in the } \\ \text { following collection(s): } \\ \text { All Pediatric } \\ \text { http://n.neurology.org/cgi/collection/all_pediatric } \\ \text { Botulinum toxin } \\ \text { http://n.neurology.org/cgi/collection/botulinum_toxin } \\ \text { Guillain-Barre syndrome } \\ \text { http://n.neurology.org/cgi/collection/guillainbarre_syndrome } \\ \text { Information about reproducing this article in parts (figures,tables) or in } \\ \text { its entirety can be found online at: } \\ \text { http://www.neurology.org/about/about_the_journal\#permissions } \\ \text { Information about ordering reprints can be found online: } \\ \text { http://n.neurology.org/subscribers/advertise }\end{array}$

Neurology ${ }^{\circledR}$ is the official journal of the American Academy of Neurology. Published continuously since 1951, it is now a weekly with 48 issues per year. Copyright @ 2021 American Academy of Neurology. All rights reserved. Print ISSN: 0028-3878. Online ISSN: 1526-632X.

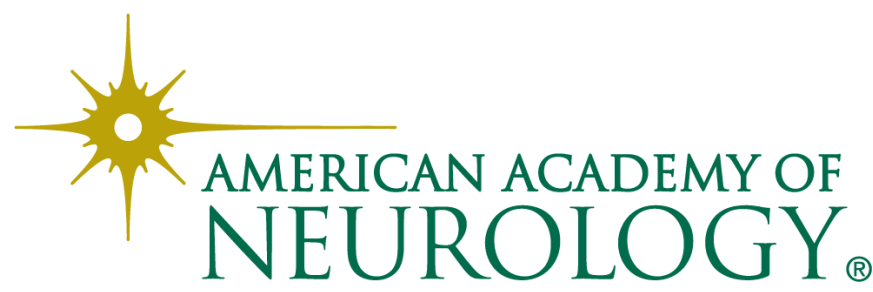

